\title{
EFFECT OF KNOWLEDGE ON PUPILS' PHYSICAL ABILITIES
}

\author{
Aurimas Medonis, Vincentas Blauzdys \\ Vilnius Pedagogical University, Vilnius, Lithuania
}

Aurimas Medonis. PhD student in Social Sciences, Education (Sport Science), at the Department of Physical Education Theory, Vilnius Pedagogical University. Research interests — pupils' physical education at secondary school and gymnasium.

\begin{abstract}
National educational institutions constantly endeavor their efforts at development of democracy and humanism. In the process of pupils'development as a personality, a very important role for democracy appears to be school physical education, as it affords necessary knowledge and develops skills for its purposeful application both in physical education lessons and at their leisure time. However, research data show that still many pupils do not possess appropriate knowledge and skills for a conscious and purposeful choise of physical education content, as well as for grounding its application technologies by valid reasons. Searching for the answer, the object of the research was physical education knowledge, and the aim of the research was targeted at the establishment of the $10^{\text {th }}$ form schoolboys' physical education knowledge effect on the change of their physical abilities.

The article provides analysis of the $10^{\text {th }}$ form schoolboys'need for physical education knowledge by their self-compiled and performed complexes of physical exercises. This need is discussed referring to General Physical Education Program and Education Standards (2003). The object of this research is a part of pupils 'physical education content and methods, and, what is most important - it is in relation with values and objectives which base school activity, as well as with contemporary physical education and self-education holistic trend. Following this attitude, the participants of the research were not stimulated for the development of maximum physical abilities, they were expected to improve their physical fitness moderately, following the guidelines established in General Program and Education Standards.
\end{abstract}

The methods applied in the research were the following: analysis of literature, questionnaire survey, testing of physical abilities and statistical analysis.

Having performed the educational experiment, it was established that purposeful and consistently compiled development system of physical abilities which is based on natural physical activity of a young person, his physical capacities and needs, improves attitude towards self-exercising during physical education lessons, also stimulates to achieve more knowledge from physical education teachers, and due to this increases satisfaction with physical education lessons.

The working assumption stating that personally compiled physical education exercises complex for development of their weaker physical abilities will be more effective for the improvement of attitude towards self-exercising during lessons, as well as sporting activities when the lessons are over. However, it is essential to indicate the fact that a certain part of the investigated schoolboys maintained the same low level of knowledge both before and after the experiment. Bearing this in mind, and referring to Primary and Basic Education General Programs (2008), physical education teachers should supply physical education knowledge, and pupils should perceive it and use it in a more effective way.

Schoolboys of E group (carrying out the experimental program) throughout the whole experiment period exposed higher results of physical abilities compared to K group results. The better results were influenced by personal physical education and self-education motives and aims, possibility to compile physical exercises complex and perform it.

Keywords: pupils'knowledge, effect, physical abilities.

\section{INTRODUCTION}

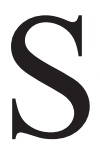
trategic documents of Lithuanian Republic raise the aim — to adapt the content of education so that each pupil would be able to grow up as a personality according to his/her needs and possibilities, to acquire competences indispen- sable for future learning and for meaningful as well as active life in contemporary society (Strategy of General Education Contents Formation, Evaluation, Updating and Implementation, 2007, further on Strategy on Education Content). 
Development of general and specific movement, health strengthening and its consideration provides more possibilities to express person's physical and creative activity and particularity.

In the period of adolescence, it is of paramount importance to develop adaptational and social skills of pupils, to combine psychosomatic maturity and interests, and to develop needs for physical self-expression and movement (Primary and Basic Education General Programs, 2008).

These programs mentioned above as Cavill and his colleagues (2006) stated, provide recommendations for the $9^{\text {th }}-10^{\text {th }}$ form pupils to learn analysing the ways of health strengthening and its consideration, satisfy needs for self-development and physical activity, as well as needs for joy of movement, increase responsibility for one's health and physical education quality. It is also recommended to compile and perform various physical exercises complexes, show interest in them, choose non-traditional physical activity forms, learn to create, think, provide and implement. All those things are not sufficiently performed both by pupils and physical education teachers. Besides, Strategy on Education Content (2007) also indicates weak points in other school subject contents implementation, so the need for quality general and physical education content implementation remains urgent. Research by K. Kardelis and others (2001) National Association for Sport and Physical Education (2002), R. Lowry, M. Brener (2004), V. Blauzdys, A. Vilkas (2006), V. Blauzdys, L. Bagdonienė (2007) and others bring up the existing problem to be solved - selection of the content for the development of appropriate physical abilities for pupils by teachers and pupils, search for relation between that selection and choice when transiting from supervision of pupils to stimulating them for self-development. Due to what is said, it is essential to bear knowledge on physical abilities development content choice and be aware of technologies to foster positive and conscious pupil's attitude towards exercising formation as well as development of one of health basis, i. e. - physical abilities.

One of the main and the most effective ways to expand knowledge is supposed to be purposeful collaboration with a teacher. Nevertheless, knowledge supplying during physical education lesson often meets various obstacles. Awareness of pupils' already possessed knowledge is also very important. Establishment of the latter is a rather difficult task as acquired knowledge usually trans- forms in various ways (Burton, 2008). This is in relation with the problem of our research.

The aim of the research was to establish the $10^{\text {th }}$ form schoolboys' physical education knowledge effect on the change of their physical abilities.

\section{The tasks of the research:}

1) to find out the $10^{\text {th }}$ form schoolboys' opinion on the means of development of physical abilities, benefits of physical exercises and attitudes towards exercising results;

2) to establish the change in the indices of schoolboys' physical abilities applying the methods of experiment.

\section{METHODS OF THE RESEARCH}

Educational experiment was carried out from January 9, 2006 till May 22, 2006 in one Vilnius gymnasium and one Vilnius secondary school. 59 schoolboys of the $10^{\text {th }}$ form, belonging to basic medical physical fitness group participated in the experiment. In each school, experimental (E - 3 in total) and control ( $\mathrm{K}-4$ in total) classes were randomly selected.

The independent variable was a compiled questionnaire on the development of new physical abilities and self-development during physical education lessons and in their leisure time, based on each pupil's compiled physical exercises complex for development of the chosen physical abilities. Dominant strength abilities were explosive strength and endurance strength. The exercises were performed elaborating the largest muscles of legs and upper body. Endurance strength development requires willpower efforts, so the research participants were supplied with knowledge about the impact of exercises' on the human body, health, body shape and the importance of physical abilities in one's life. Physical abilities were developed moderately, and the norms of exercise achievements, provided in physical education standards, were kept to. This method increased the knowledge on physical education, consolidated self-learning as personality was developed in a more purposeful way: physical education and social skills were developed in parallel with the development of individual responsibility. It was applied for the experimental group pupils, who were able to choose exercises from provided versions and invent their own exercises; all this was implemented in 2 weekly lessons. Besides, the complex of the exercises was recommended to be performed in leisure time as well, at least once a week. 
$\mathrm{K}$ group pupils did not perform complexes, they had usual physical education lessons incorporating traditional means and methods of the development of physical abilities, i. e., sport games.

Questionnaire survey. The aim of it was to establish the pupils' knowledge on physical abilities, content and technologies of their development.

Results of the $10^{\text {th }}$ form schoolboys 'physical abilities were established during the year of 2006. $\mathrm{E}$ and $\mathrm{K}$ group pupils were tested in January and May. E and K group pupils' physical ability results were observed, compared, analyzed at the beginning and at the end of the educational experiment; the results disclosed the tendencies of the experimental program.

Statistical analysis. Differences in the questionnaire survey results were evaluated applying Chi square $\left(\chi^{2}\right)$ criterion. Results of physical abilities were provided indicating their arithmetical means $(\overline{\mathrm{X}})$, standard deviation (s), arithmetical mean error $(S \bar{x})$, variation coefficients $(v)$,
Student's tests (t), significance of the differences (reliabilities) (p). The level of the significance of the differences was interpreted according to B. Bitinas (2006). The data of the research was processed by STATISTICA and MS EXCEL computer programs.

\section{RESULTS}

Physical education process during physical education lessons was regulated by Physical Education General Program and Education Standards (2003) approved by Lithuanian Ministry of Education, so our performed questionnaire survey, beside the other facts, disclosed the situation about the program integration into the $10^{\text {th }}$ form male pupils' physical development process.

The majority of the pupils were aware of what physical abilities they develop during physical education lessons (Fig. 1). Exact answers were provided by $25.0 \%$ (the first inquiry) and $29.2 \%$ (the
Figure 1. Percentage distribution of awareness of physical abilities which were developed by the schoolboys during physical education lessons
Figure 2. Schoolboys' attitudes towards exercising during physical education lessons
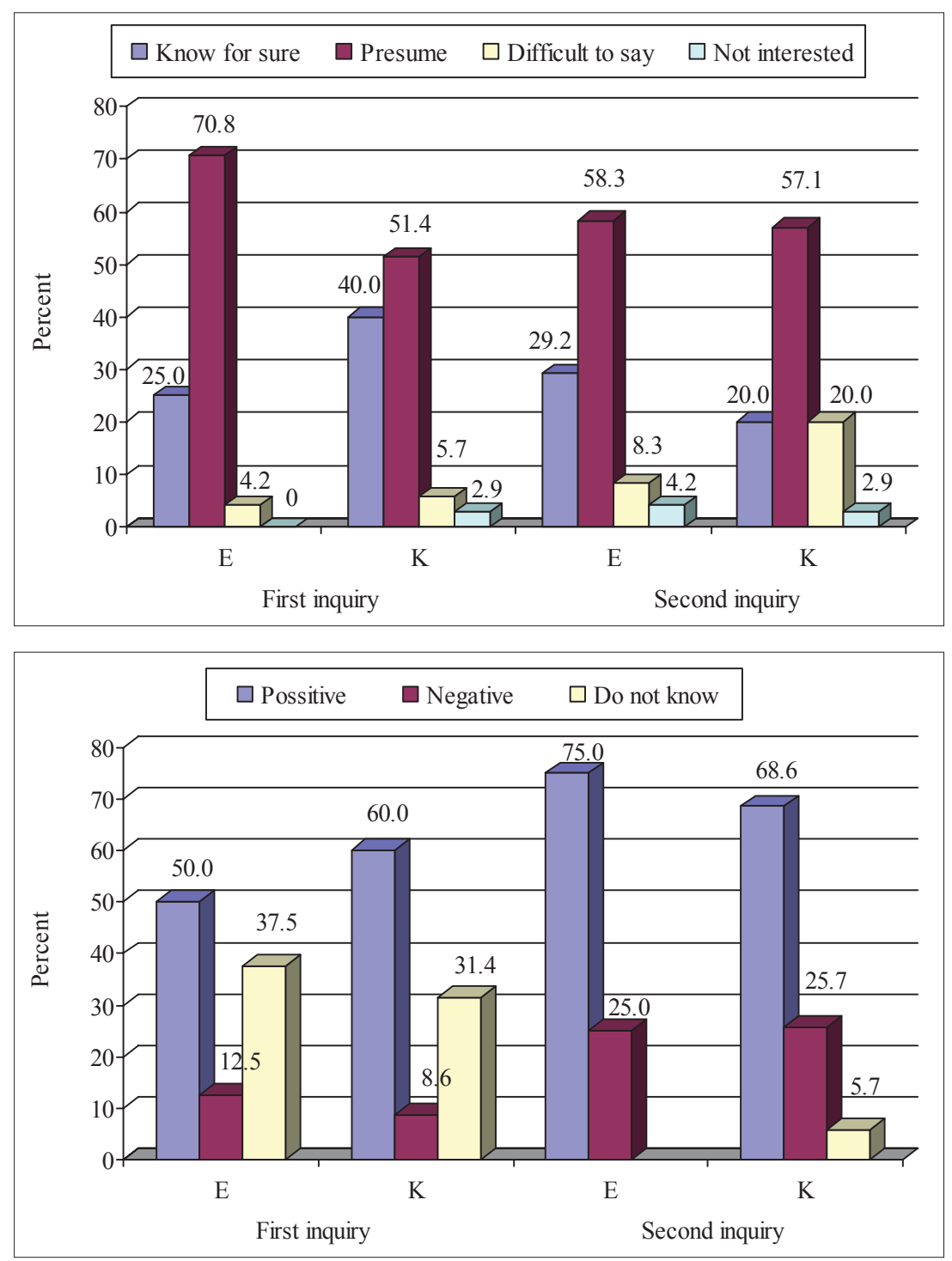
Table 1. Indices of E group schoolboys' physical abilities

\begin{tabular}{|c|c|c|c|c|c|c|c|c|}
\hline $\begin{array}{l}\text { Group } \\
\text { E }\end{array}$ & Indices & $\begin{array}{l}\text { Squats down } \\
\text { and up, times }\end{array}$ & $\begin{array}{l}\text { Pull-ups, } \\
\text { times }\end{array}$ & $\begin{array}{c}\text { Arm wrestling, } \\
\text { times }\end{array}$ & Sit-ups, times & $\begin{array}{c}\text { Standing long } \\
\text { jump, } m\end{array}$ & $\begin{array}{c}10 \times 5 \mathrm{~m} \\
\text { shuttle run, } \mathrm{s}\end{array}$ & $\begin{array}{l}\text { Standing on one } \\
\text { leg, eyes closed, } \mathrm{s}\end{array}$ \\
\hline \multirow{3}{*}{$\begin{array}{l}\text { I testing } \\
\text { in winter } \\
\text { (January) }\end{array}$} & $\overline{\mathrm{x}} \pm \mathrm{S} \overline{\mathrm{x}}$ & $60.79 \pm 7.92$ & $4.58 \pm 0.81$ & $34 \pm 2.35$ & $29.38 \pm 0.63$ & $2.19 \pm 0.03$ & $18.3 \pm 0.22$ & $13.39 \pm 2.22$ \\
\hline & $\mathrm{S}$ & 38.78 & 3.98 & 11.5 & 3.1 & 0.17 & 1.01 & 10.87 \\
\hline & $\mathrm{V}$ & $63.8 \%$ & $86.9 \%$ & $33.8 \%$ & $10.5 \%$ & $7.7 \%$ & $5.5 \%$ & $81.2 \%$ \\
\hline \multirow{3}{*}{$\begin{array}{l}\text { II testing } \\
\text { in spring } \\
\text { (March) }\end{array}$} & $\overline{\mathrm{X}} \pm \mathrm{S} \overline{\mathrm{X}}$ & $61.21 \pm 7.45$ & $5 \pm 0.88$ & $35.88 \pm 2.25$ & $30.08 \pm 0.56$ & $2.22 \pm 0.04$ & $18.07 \pm 0.18$ & $14.73 \pm 3.01$ \\
\hline & $\mathrm{S}$ & 36.50 & 4.33 & 11.02 & 2.75 & 0.18 & 0.89 & 14.76 \\
\hline & $\mathrm{V}$ & $59.6 \%$ & $86.6 \%$ & $30.7 \%$ & $9.1 \%$ & $8.1 \%$ & $4.9 \%$ & $100.2 \%$ \\
\hline \multirow{6}{*}{$\begin{array}{l}\text { III testing } \\
\text { in spring } \\
\text { (May) }\end{array}$} & $\overline{\mathrm{x}} \pm \mathrm{S} \overline{\mathrm{x}}$ & $78.33 \pm 7.35$ & $6 \pm 0.99$ & $37.54 \pm 2.29$ & $30.88 \pm 0.49$ & $2.25 \pm 0.03$ & $17.88 \pm 0.18$ & $17.6 \pm 2.84$ \\
\hline & $\mathrm{S}$ & 35.99 & 4.87 & 11.21 & 2.42 & 0.19 & 0.87 & 13.93 \\
\hline & $\mathrm{V}$ & $45.9 \%$ & $81.2 \%$ & $29.9 \%$ & $7.8 \%$ & $8.4 \%$ & $4.9 \%$ & $79.1 \%$ \\
\hline & $\mathrm{d}$ & 17.54 & 1.42 & 3.54 & 1.5 & 0.06 & 0.42 & 4.21 \\
\hline & $\mathrm{t}$ & 1.62 & 1.11 & 1.08 & 0.83 & 1.43 & 1.5 & 1.17 \\
\hline & $\mathrm{p}$ & $p>0.2$ & $\mathrm{p}>0.4$ & $\mathrm{p}>0.4$ & $\mathrm{p}>0.5$ & $\mathrm{p}>0.2$ & $\mathrm{p}>0.2$ & $\mathrm{p}>0.4$ \\
\hline
\end{tabular}

Note. $\mathrm{p}$ - statistical evaluation of difference between first and third testing $(\overline{\mathrm{X}})$ indices.

Table 2. Indices of K group schoolboys' physical abilities

\begin{tabular}{|c|c|c|c|c|c|c|c|c|}
\hline $\begin{array}{c}\text { Group } \\
\text { K }\end{array}$ & Indices & $\begin{array}{c}\text { Squats down } \\
\text { and up, times }\end{array}$ & $\begin{array}{c}\text { Pull-ups, } \\
\text { times }\end{array}$ & $\begin{array}{c}\text { Arm wrestling, } \\
\text { times }\end{array}$ & Sit-ups, times & $\begin{array}{c}\text { Standing long } \\
\text { jump, m }\end{array}$ & $\begin{array}{c}\mathbf{1 0} \times \mathbf{5} \mathbf{m} \\
\text { shuttle run, s }\end{array}$ & $\begin{array}{c}\text { Standing on one } \\
\text { leg, eyes closed, s }\end{array}$ \\
\hline \multirow{2}{*}{$\begin{array}{l}\text { I testing } \\
\text { in winter } \\
\text { (January) }\end{array}$} & $\overline{\mathrm{X}} \pm \mathrm{S} \overline{\mathrm{X}}$ & $49.91 \pm 4.24$ & $5.77 \pm 0.69$ & $30.54 \pm 1.6$ & $27.08 \pm 0.58$ & $2.21 \pm 0.03$ & $18.93 \pm 0.23$ & $8.61 \pm 0.93$ \\
\cline { 2 - 10 } & $\mathrm{S}$ & 25.1 & 4.07 & 9.47 & 3.45 & 0.19 & 1.37 & 7.52 \\
\hline
\end{tabular}

Note. $\mathrm{p}$ - statistical evaluation of difference between first and second testing $(\overline{\mathrm{X}})$ indices.

second inquiry) of E group and respectively 40.0 and $20.0 \%$ of $\mathrm{K}$ group pupils; presumptions on the issue were given by 70.8 and $58.3 \%$ of the E group and 51.4 and $57.1 \%$ of the $\mathrm{K}$ group pupils. However, no one of $10^{\text {th }}$ form pupils was able to provide exact names of all physical abilities. The majority of the pupils named only one physical ability.

Similar situation was observed when the subjects were asked to name their weaker physical abilities. The majority of the $10^{\text {th }}$ form pupils were unable to name their weaker physical abilities: 54.2 and $37.5 \%$ of E group and even 71.4 and $68.5 \%$ of $\mathrm{K}$ group pupils. Response difference between $\mathrm{E}$ and $\mathrm{K}$ group pupils after the experiment was statistically significant $(\mathrm{p}<0.05)$.

The majority of the schoolboys expressed their opinion that physical abilities are best developed by learnt sport games. This was stated by 62.5 and $75.0 \%$ of E group and 45.7 and $74.3 \%$ of $\mathrm{K}$ group pupils $(\mathrm{p}<0.05)$. It also became clear that none of the E group pupils saw one exact physical exercise as a mean to develop physical abilities during physical education lessons. This fact indicates that E group schoolboys were more sophisticated in comparison to the ones of $\mathrm{K}$ group.

The investigated schoolboys stated that physical abilities could be best developed at home: by one exact exercise - 4.2 and $20.8 \%$ of E group and 14.3 and $11.4 \%$ of $K$ group pupils; by several exercises at once - $58.3 \%$ of E group and 60.0 and $20.0 \%$ of $\mathrm{K}$ group pupils. After the experiment, statistically significant difference $(p<0.05)$ was established between $\mathrm{E}$ and $\mathrm{K}$ group schoolboys' opinions. The best way to develop physical abilities was to compile complexes of individual physical exercises. Both times this was stated by $20.8 \%$ of E group and 14.3 and $68.5 \%(p<0.05)$ of $\mathrm{K}$ group pupils. An interesting fact was observed: when the school year was over, this statement was supported by significantly increased number of $\mathrm{K}$ group pupils, it was also significantly different from E group pupils.

The responses from the investigated schoolboys exposed the fact that 33.3 and 12.5 and 
$12.5 \%$ of E group and 17.1 and $22.9 \%$ of K group pupils were not developing their physical abilities at home. Nevertheless, there was observed a little increase in the number of $\mathrm{E}$ group pupils, performing physical exercises complex, while in $\mathrm{K}$ group this number decreased.

The research established that the majority of the schoolboys - both times $58.3 \%$ of the E group and $57.1 \%$ and 58,3 of the $\mathrm{K}$ group respondents gave the most positive evaluation of sport games during the physical education lesson, and the other content of the lessons deserved less attention.

The research results showed that the $10^{\text {th }}$ form schoolboys' received knowledge on the benefits of physical exercises for the human body was different. As it was established, rather great part of the subjects - 37.5 and $50.0 \%$ of the E group and 37.1 and $28.6 \%$ of the $\mathrm{K}$ group pupils were much interested in their health on their own. It became clear that 20.8 and $16.7 \%$ of the E group and 17.1 and $34.3 \%$ of the $\mathrm{K}$ group pupils received the greatest amount of knowledge on the benefit of physical exercises for the human body from their physical education teacher during their physical education lessons.

The research showed the positive attitude towards self-exercising by the majority of the research participants (Figure 2).

Self-exercising during physical education lessons was most positively evaluated by the majority of the schoolboys: 50.0 and $75.0 \%$ of the E group and 60.0 and $68.6 \%$ of the K group pupils. During the experiment, statistically significant decrease $(\mathrm{p}<0.05)$ was observed in $\mathrm{K}$ group pupils who did not posses clear attitudes towards exercising.

During the experiment, the results of $E$ and $\mathrm{K}$ group pupils' physical abilities were gradually increasing (Tables 1 and 2). Worth attention is the fact that E group pupils' leg strength endurance (test "Squat down and up on both legs") increased by 17.5 times, and in K group - by 12.9 times.

\section{DISCUSSION}

The system of education, being under the influence of environmental challenges, keeps searching for the most effective technologies for general and physical education. In this search, knowledge is of paramount importance as it is considered to be the main part stimulating educational process development and perfection. Already possessed knowledge does not influence better results of selfexercising; educational changes are needed to de- termine this better result achievement (Blauzdys, 2007). For this reason, during the experiment the $10^{\text {th }}$ form schoolboys were stimulated to acquire knowledge on physical abilities and their impact on body's functional systems.

Educational process starts at raising the aim, it concentrates and directs thinking and activity in desirable direction. New learning strategies require each person's development in learning skills and establish relevant to him / her objectives (Weeden et al., 2005). Also, knowledge on the means and technologies of development of physical abilities was necessary, introducing this important educational aspect into the tasks of the experimental lessons. This knowledge increased understanding that chosen physical ability development means and technologies, as well as various results of them are the value. Aiming at the latter, we based our experiment on R. Vasiliauskas (2005) and B. Bitinas (2006) statement that value formation in contemporary educational activity is to be started from high motivation system creation, particular attention paying at partnership like collaboration between pupils and teachers.

The main aim of the teacher is to assist pupils in teaching-learning process, as predominant activity conducted only by a teacher is not relevant and useful. Striving for higher effectiveness of this process, it is necessary to possess knowledge and understanding about technologies which influence its quality. Due to this, it is very important to develop such teaching-learning theories and strategies which would bear and be supplied in small amount of knowledge so that pupils would be able to concentrate their attention upon it, feel safe while looking for explanations and support (Halliday, 2005).

In our case, this was the only useful way to achieve expected physical teaching-learning results, corresponding to our holistic nature of education. So it is quite understandable why physical education in contemporary secondary school physical education change system is considered as an activity embracing the development of pupils' psychomotor skills, concentrating their essential knowledge, also developing individual attitude towards exercising as a value. Need for self-exercising appears not only due to external influence, but also to person's inner interests (Blauzdys, 2007). To confirm person's interests, beside other aspects, knowledge is essential. Unfortunately, in our case the investigated pupils' level of knowledge about the development of physical abilities was low. This can be an outcome of changes which occur in 
secondary school, attempting for democratization and humanization of physical education lessons content and applied education methods (Vilkas, 2005; Blauzdys, Vilkas, 2007), while amount of knowledge is being reduced. The lack of knowledge has been observed also by other researchers. According to K. Kardelis and others (2001), pupils in higher forms bear rather low level of knowledge about physical education. They can tell a little more only about sport games. Pupils should be more stimulated to get interested in physical education and be provided more knowledge during physical education lessons.

It was proved that the main motive of the $5-12^{\text {th }}$ forms pupils' self-exercing and sporting is hedonistic, i. e., feeling of pleasure, and due to insufficiently developed motivation it is hardly credible that pupils exercise regularly (Vilkas, Raškauskiene, 2005). This factor could be of influence on our investigated $10^{\text {th }}$ form schoolboys' physical abilities and their change. It is also possible to expect greater need for knowledge and its effectiveness with prolonged period of the investigation.

However, questionnaire survey results revealed that educational experiment had a positive effect on the $10^{\text {th }}$ form schoolboys' attitude towards physical abilities and their development means, technologies and desirable education content formation. Besides, E group pupils' questionnaire responses showed greater correspondence of their knowledge with basic skills and achievements content for the $10^{\text {th }}$ form indicated in Physical Education General Program (2003), compared to K group pupils.

The results of the research confirmed T. Rowland (1990), V. Blauzdys, L. Bagdonienè (2007) statements about physical education success being dependent on skills for meaningful organization and combination of activity character and content. Physical education model, which is hard and requires great physical and mental efforts develops negative physical activity motivation and is condemned to experience failure. Physical education should develop values and activity forms, meaningful for a pupil; being such it has real possibilities to become effective mean for person's development and self-expression (Blauzdys, Bagdonienè, 2007).

\section{CONCLUSIONS}

1. A little increase was observed in a number of both groups schoolboys stating that physical abilities can be best developed by using sport games during physical education lessons, and at home - by one certain exercise (in E group) and by individual complex of physical exercises (in K group). Besides, there was a decrease in the number of E group pupils - from 33.3 to $12.5 \%$ who confessed not developing their physical abilities at home, while in K group the number of such pupils increased from 17.1 to $22.9 \%$. Pupils in both groups had the most positive evaluation of sport games played during physical education lessons. Only one person from each of the two investigated groups did not know the benefits of the performed exercises, the others usually knew such benefits in the way it was provided by physical education teacher during physical education lessons. Attitudes towards exercising during physical education lessons and satisfaction with their results improved, especially for E group schoolboys.

2. Summarizing the research results we suggest that during the experiment $\mathrm{E}$ and $\mathrm{K}$ groups schoolboys' physical qualities results were gradually improving, although the results of $\mathrm{E}$ group pupils did not have statistically significant change. Physical abilities of these pupils were sufficiently developed as the tests results were in accordance with quantity orientation norms of Physical Education General Program and Education Standards (2003).

After the experimental impact, E group schoolboys' results in even four tests from the applied seven ones were significantly higher than those of $\mathrm{K}$ group pupils.

\section{REFERENCES}

Bendrojo lavinimo ugdymo turinio formavimo, vertinimo, atnaujinimo ir diegimo strategija. (2007). Vilnius: MM. Internet link: http://www.smm.lt/ugdymas/docs/ uts/2007\%2005\%2023\%20UT\%20strategija.pdf.

Bitinas, B. (2006). Edukologinis tyrimas: sistema ir procesas. Vilnius: Kronta. P. 304.

Blauzdys, V., Bagdonienè, L. (2007). Mokiniu teigiamo požiūrio ì kūno kultūrq kaip mokymosi dalyko ugdymas, didinant jo prasminguma: monografija. Vilnius: VPU.
Blauzdys, V. (2007). Mokiniu išsikeltu fizinio ugdymosi tikslu igyvendinimo pasekmés. Pedagogika, 88, 76.

Blauzdys, V., Vilkas, A. (2006). Influence of knowledge of physical training on the physical fitness of girls and boys at the third class of gymnasium. In Movement and Health: Proceedings. Opole: University of Technology. P. 93-102.

Burton, D. (2008). Understanding learning theories and strategies. Supporting Teaching and Learning in Schools: 
A Handbook for Higher Level Teaching Assistants. Edited by S. Younie, S. Capel, M. Leask. USA: New York, Routledge, Tailor and Francis group. P. 83-85.

Cavill, N., Kahlmeier, S., Racioppi, F. (2006). World health organization. Physical Activity and Health in Europe: Evidence for Action. Denmark: Copenhagen.

Halliday, J. (2005). Technicism, reflective practice and authenticity in teacher education. Teacher education. Major Themes in Education. Edited by D. Hartley, M. Whitehead. Routledge, USA: New York, Tailor and Francis group. P. 113-127.

Kardelis, K., Kavaliauskas, S., Balzeris, V. (2001). Mokykline kūno kultūra: realijos ir perspektyvos: monografija. Kaunas: LKKA.

Kūno kultūra. (2003). Bendrosios programos ir išsilavinimo standartai: priešmokyklinis, pradinis ir pagrindinis ugdymas. Vilnius: ŠAC. P. 627-631.

Lowry, R., Brener, M., Lee, S. (2004). Parcitipation in High School Physical Education. Atlanta, United States, 1991-2003: Center for Disease Control and Prevention.
National association for sport and physical education. (2002). Adults / Teens Attitudes toward Physical Activity and Physical Education. Washington, USA. Internet link: http://www.aahperd.org/naspe/survey.html.

Pradinio ir pagrindinio ugdymo bendrosios programos. (2008). Vilnius: MM.

Rowland, T. (1990). Exercise and Children's Health. Champaign, IL: Human kinetics.

Vasiliauskas, R. (2005). Vertybiu pedagogika: jžvalgos $i$ vertybiu ugdymo teorija ir praktikq. Vilnius: VPU.

Vilkas, A. (2005). Paaugliu fiziniu gebejjimu ir funkcinio pajègumo kaita dèl fizinio ugdymo ir juvairiu fiziniu krūviu: habilitacijos procedūrai teikiamu mokslo darbu apžvalga. Vilnius: VPU.

Vilkas, A., Raškauskienè, J. (2005). 5-12 klasių mergaičiu požiūrio ỉ kūno kultūrą formavimasis ir kaita. Sporto mokslas, 3 (41), 67-71.

Weeden, P., Winter, J., Broadfoot, P. (2005). Vertinimas. Ka tai reiškia mokykloms? Vilnius: Garnelis.

\title{
ŽINIŲ POVEIKIS MOKINIŲ FIZINĖMS YPATYBĖMS
}

\author{
Aurimas Medonis, Vincentas Blauzdys \\ Vilniaus pedagoginis universitetas, Vilnius, Lietuva
}

\section{SANTRAUKA}

Šalies ugdymo institucijų pastangos krypsta į demokratijos ir humaniškumo ugdymą. Ugdant mokini kaip asmenybę, demokratijai svarbus ir mokyklinès kūno kultūros vaidmuo: teikti tam reikalingų žinių, ugdyti gebèjimą jas prasmingai taikyti ne tik per kūno kultūros pamokas, bet ir laisvalaikiu. Deja, tyrimai rodo, kad didelè mokinių dalis dar neturi reikiamų žinių bei gebẻjimų sąmoningai ir tikslingai pasirinkti fizinio ugdymosi turini, svariais argumentais grịsti jo taikymo technologijas. Ieškant atsakymo, tyrimo objektu buvo pasirinktos kūno kultūros žinios, o tyrimo tikslu siekta nustatyti X klasès vaikinų kūno kultūros žinių poveikị jų fiziniu ypatybių kaitai.

Straipsnyje analizuojamas X klasės vaikinų susidarytų ir atliktų fiziniu pratimų kompleksų skatinamasis kūno kultūros žiniu poreikis. Jis aptariamas remiantis Bendraja kūno kultūros programa ir išsilavinimo standartais (2003). Šio tyrimo objektas yra mokiniu fizinio ugdymo turinio ir metodikos dalis, o svarbiausia, jis yra siejamas su mokyklos veiklą grindžiančiomis vertybėmis ir siekiais, šiuolaikine fizinio ugdymo(-si) holistine kryptimi. Todèl tiriamieji nebuvo skatinami siekti maksimalių fizinių ypatybių lavinimosi rezultatų, o saikingai gerinti fizini parengtumą pagal Bendrosios programos ir išsilavinimo standartų nubréžtas ribas.

Taikyti šie tyrimų metodai: literatūros šaltinių analizė, anketinè apklausa, fizinių ypatybių testavimas, statistinè analizè.

Po ugdomojo eksperimento paaiškejjo, kad kryptinga, nuosekliai sudaryta fizinių ypatybių lavinimo sistema, kuri remiasi natūraliu jaunuolio fiziniu aktyvumu, jo fizinėmis išgalèmis ir poreikiais, gerina požiūri i mankštinimąsi per kūno kultūros pamokas, skatina daugiau gauti žinių iš kūno kultūros mokytojų ir todèl didina pasitenkinimą kūno kultūros pamoka. Pasitvirtino darbinė prielaida, kad asmeniškai susidarytas fizinių pratimų kompleksas silpniau išlavintoms fizinėms ypatybėms lavinti veiksmingiau gerins požiūrị i mankštinimąsi per pamokas ir sportavimą po jų. Vis dèlto būtina pažymėti, kad dalies tirtų vaikinų žinios prieš ugdomaji eksperimentą ir po jo išliko prastos. Todèl kūno kultūros mokytojams, remiantis Pradinio ir pagrindinio ugdymo bendrosiomis programomis (2008), reikètų veiksmingiau teikti, o ugdytiniams sąmoningiau ir kokybiškiau pasisavinti kūno kultūros žinias, jas prasmingiau panaudoti.

Eksperimentinę programą vykdžiusių E grupės vaikinų fizinių ypatybių rezultatai visą eksperimento laikotarpi buvo geresni už tuos pačius $\mathrm{K}$ grupès rezultatus. Tam turèjo itakos asmeniniai fizinio ugdymo(-si) motyvai ir tikslai, galimybè susidaryti fizinių pratimų kompleksą, jo atlikimo metodika.

Raktažodžiai: mokinių žinios, poveikis, fizinès ypatybès.

Gauta 2009 m. sausio 29 d.

Received on January 29, 2009 